The contrasts between South Africa and the preceding study of Bangladesh offer a first taste of important variations in elite perceptions from country to country, which our research team will develop more fully in longer studies of these two and several other cases. Alongside the homogeneous Bangladeshi elite (singular) concentrated mainly in one city, stand South Africa's diverse elites (plural) dispersed among numerous urban centres which are separated by great distances and much else besides.

Both of these societies (and most of the others that are being studied in our larger project) are, unlike most in the West, segmented. But the character of segmentation in South Africa and Bangladesh differs in several important respects. This affects perceptions both of the obligations of elites to the poor within their social segments, and of the responsibility of the whole society and of the government to the poor in general.

While the Bangladeshi elite is undivided by any great political or social cleavage and has a roughly unified view of poverty, an important fault line runs right through South Africa's elites. It separates the ruling ANC elite, which (despite some internal variations) tends to perceive poverty in ways akin to European social democrats, from most other South African elites who stop well short of that outlook. The ANC elite tends to regard poverty as an urgent problem that can and must be tackled by direct, targeted efforts by government - in contrast to Bangladeshi elites and, indeed, to most other South African elites. But they are (so far, at least) hamstrung by unfavourable international conditions and, not least, by the hesitations of nearly all other elites in their society.

\footnotetext{
Our field research was undertaken in and around four South African cities (Durban, Pretoria, Johannesburg and Cape Town) February-April, 1998. It was funded, through the Institute of Development Studies Poverty Programmes, by a grant from Britain's Department for International Development. We are especially grateful to Mike Morris and his colleagues at the Centre for Social and Development Studies, University of Natal-Durban for vital assistance. Thanks are also due to numerous scholars at the Universities of Pretoria, the Witwatersrand, and Cape Town, and to over 100 members of selected elites who gave patiently of their time for extensive, semi-structured interviews.
}

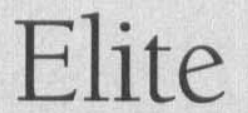

\section{Perceptions of Poverty:} South Africa

\section{Noushin Kalati and James Manor'}


In South Africa, as in Bangladesh, there is no immediate sense among elites that social and political unrest poses threats. Politics, for the present, has demobilised the poor - or rather it has mobilised them for electoral purposes while containing pressure for social transformation. But transformation has been promised - indeed, oversold - by the ANC. That party therefore finds itself playing incompatible roles, simultaneously promising transformation and containing pressure for transformation while it seeks to tackle poverty through the pursuit of economic growth. Most members of the ANC elite are aware of the dissonance between these roles and of painfully slow progress in the drive for growth.

So, in South Africa, unlike Bangladesh, the current dispensation is seen by the ruling elite (but not most other elites) as very likely a temporary phenomenon. Unless growth takes off within a very few years (which is improbable), vigorous efforts at redistribution will become a political necessity. If (when) that day comes, the ANC elite will face a painful encounter with the complacent, hesitant perceptions of most other South African elites.

There is insufficient space here to explore the full array of elite perceptions in South Africa. So we concentrate on two crucial themes: (i) the distinctive character of social segmentation there and the problems that it raises, especially for the new ruling elite, and (ii) the response (so far) of the ANC elite.

South Africa is one of the most inequitable societies on earth, ${ }^{2}$ although the elites that we encountered mostly failed to recognise that fact. ${ }^{3}$ They live in a 'first world' milieu, alongside large numbers of extremely poor urban dwellers, and surrounded by rural areas where poverty is still more severe and widespread. Elites are aware of urban poverty, mainly because they are intensely preoccupied with the problem of crime, which they associate with the urban poor. But the greater problem of rural poverty remains largely invisible to them.

We began by studying whether South African elites had what Abram de Swaan has called a 'social consciousness' - a set of perceptions which developed in Western Europe and North America, and which helped to open the way to the creation of welfare states there. A 'social consciousness' exists when elites develop:

(a) an awareness of the interdependence of all social groups

(b) a realisation that elites bear some responsibility for the sufferings of the poor

(c) a belief that efficacious means of assisting the poor exist or might be created [De Swaan, 1988]

We found that most members of South Africa's elites have a less-than-fully-developed 'social consciousness'. In brief, they tend to lack a strong awareness of the first two propositions listed above, especially the second. Their faith in efficacious means tends to be rather vague, and to fix on economic growth. A growth strategy tends to absolve elites of responsibility for poverty. They blame it on apartheid, for which few accept any responsibility. The pursuit of growth also makes elites appear to be part of the solution (as generators of growth), rather than as part of the problem. But as the months roll by, growth appears increasingly unlikely to make much impact.

The ruling elite of the African National Congress (ANC) is, however, distinctly different. It possesses a clear social consciousness on each of the three counts listed above. This represents a curious reversal of the

\footnotetext{
2 See for example the Deininger and Squire data set, available on the World Bank's web site.

${ }^{3}$ Like our colleagues doing similar studies in other countries, we interviewed members of 11 different elites: (1) politicians in power; (2) politicians in opposition; (3) people working in the media; (4) influential academics and professionals; (5) union leaders (in both blue and white collar unions); (6) business executives, large-scale entrepreneurs; (7) leaders of voluntary associations (including those which
}

exist to serve the needs of the poor); (8) civil servants in the upper ranks; (9) high ranking military and police officers; (10) large landowners; (11) religious leaders. Within most of these elites, whites predominate heavily, but the influence of non-whites is already on the rise within nearly all of them. In anticipation of the further growth of their influence, we interviewed a somewhat larger number of non-whites, especially Africans, than current white dominance would otherwise have justified. 
situation which prevails in several other countries, where the ruling elite is less prepared than some or many other elites to contemplate efforts to tackle poverty.

This and numerous other problems place the ANC elite in a very difficult position when anti-poverty programmes and redistribution are discussed. We shall turn to that presently, but let us first explore another issue which has been comparatively unimportant in the West/North, but which looms large in all of the less developed countries that we and our colleagues are studying - the problem of social segmentation. An assessment of that is interesting in its own right, and it will carry us helpfully into a consideration of the ANC elite's excruciating dilemmas.

\section{Social Segmentation and Elite Perceptions of Poverty}

The various societies that our team are studying (South Africa, Brazil, Bangladesh, and two contrasting regions of India - Karnataka and Bihar) are similar in being segmented; that is, they are divided by lines running vertically from elites through the mass, into 'primordial' or 'ethnic' groups. ${ }^{4}$ But the character and implications of segmentation differ slightly or greatly - from case to case. We have encountered several important contrasts between South Africa and our Asian cases. These are important because they undermine a sense of personal obligation among South African elites towards poor people within their own social segments. Four are worth noting.

(i) It is not always clear what a given person's social segment is.

(ii) The social segments which are most real to South African elites tend to be larger than similar segments in South Asia.

(iii) As a result both of point (b) above and, more crucially, of the extreme inequalities which exist in South Africa, the distance (geographical, social, educational, economic, psychological) between elites and the poor within segments there tends to be greater than that which we find within most South Asian segments.

(iv) Two imperatives - to develop (i) broad political alliances within South Africa's new democratic system, and (ii) an inclusive new national identity that transcends segments also tend to undermine elites' sense of obligation to poor people within their segments.

(i) Confusion about what one's social segment is All South Africans have available to them a diversity of identities which compete with one another for their attention. A person may for example be a Xhosa, but $\mathrm{s} / \mathrm{h}$.e will also be aware of pan-African, national, regional, local, clan or family, class, urban/rural, political party, religious and other identities. Some of these identities can be seen as 'segmental' while others cannot. But since most cut across one another, their larger 'segmental' loyalties to the Xhosas, Zulus, Afrikaners or whatever tend to be undermined.

People sometimes shift their preoccupations from one to another of the various identities available to them, according to circumstance and recent events. So to ask people what social segments they belong to tends to elicit somewhat different answers at different times, and answers are sometimes multi-faceted.

Our study indicates that elite perceptions in these matters are less clear than those of people of lesser status within most segments. This tends to erode elites' sense of obligation to poor people within their segments. In this, South Africa offers a clear contrast to Bangladesh where some members of elites feel a sense of deep personal obligation towards poor people within their social segments. South Africa is more like the south Indian region of Karnataka, which we are also studying, but the problem in South Africa is severely compounded by other factors, to which we now turn.

(ii) The size of segments Social segments within South Africa tend to be quite large. Most are far larger than the endogamous caste groups (jati's) which preoccupy elites in Karnataka, or the kinship

which has considerable resonance in the new South Africa, see Manor 1996.

\footnotetext{
' The word 'ethnic' tends to be more imprecise and problematic than its widespread use in our time suggests. For an examination of this in Indian society,
} 
networks which preoccupy Bangladeshi elites. Those Asian collectivities are usually small enough to make face-to-face relations between elites and many poor people within the segment possible. The sheer size of, say, the Xhosa, Zulu, or Afrikaner categories makes it difficult for a member of an elite from one of those groups to feel personally obligated to the generality (or even to a sizeable proportion) of the poor within his or her segment.

(iii) Distance between elites and the poor within segments Most crucially, efforts by elites to address the problem of poverty within segments are further impeded by various types of distance that separate elites from poor people within social segments. Once again, this problem is much more marked in South Africa than in our Asian cases.

Members of elites often find themselves distanced from the poor geographically. This is true in two senses: (a) in terms of urban/rural or urban/periurban separations, and (b) in terms of inter-regional separations.

Poverty in South Africa is particularly serious in rural areas, while elites are overwhelmingly concentrated in towns and cities. So elites in social segments that contain large numbers of poor rural folk are spatially cut off from the poor within their own segments. This makes it easy for rural poverty to become invisible to elites in these groups, and for them to shed a sense of obligation to poor rural dwellers in their segment.

Within the great conurbations, geographical distance between areas inhabited by most elites (usually leafy suburbs) and those inhabited by the poor (squatter colonies and townships in other suburbs or near city centres) also separates elites, spatially and psychologically, from the poor in their own segments. This is especially important among black people and people of mixed race.

There is a cliche, especially among whites, that African elites are moving en masse out of townships and into formerly white suburbs. Some of that is happening, but our interviews with such elites indicate that far more of them remain in or near townships, and thus remain more concerned about poor neighbours from their own social segment than is often supposed. But the movement to the suburbs is a still a significant reality, and it will continue. So the problem of black elites being cut off from poverty among others in their segments will intensify. And since the worst urban poverty is found in squatter colonies where black elites are absent, and since squatter colonies will continue to grow, this problem will become more serious.

The distances between the regions of this large country also play a role here. In the apartheid era there was considerable spatial mobility among elites, mainly whites. In recent years, as non-whites have been freed from restrictions on their movements, such mobility has accelerated.

South Africa lacks a single, pre-eminent city in which elites are mainly concentrated. It is more like India or Germany, which have several important urban centres, than like Bangladesh or France, where one city predominates. ${ }^{5}$ It is thus common to find members of South African elites - of all descriptions these days - living at great distances from most of the people in their social segments.

Our interviews consistently indicated that these types of spatial distance erode a sense among elites of personalised obligation to the poor within their segments. And accelerating social and geographical mobility appears certain to make this problem yet more important over time.

Other types of distance compound this. Most South African elites live in comfort in a 'first world' milieu in which very high levels of income, economic development and what used to be called 'modernisation' have been achieved. But a huge proportion of the population lives in severe poverty. In other words, most members of elites stand at a considerable (and often a vast) economic distance from the poor within their social segments. Most members of elites have acquired high quality education of the 'first world' sort which puts another kind of distance between them and the poor within their segments. Our interviews again showed that such economic and educational distancing fosters an

\footnotetext{
S See note 5 in the preceding article by Hossain and Moore.
} 
enormous psychological distance between elites and poor people - in general, and within segments.

One by-product of this distancing is worth stressing. Partly as a result of their experience of a 'first world' milieu, South African elites have a greater belief than their South Asian counterparts in the capacity of impersonal, institutional forces - particularly the state and market forces - to manage society's affairs. In South Africa, both of these things are vastly more formidable than in Bangladesh and the Indian state of Bihar. They are somewhat stronger than in a comparatively prosperous Indian region like Karnataka. This makes it easier for South African elites to believe that efficacious, impersonal means exist or might be created to address the poverty of people in all social segments, and that further erodes their sense of personal obligation to poor folk within their segments.

Contrary to the prevailing belief among whites, our encounters with African leaders showed that many members of the emerging African elites still live modestly by the standards of whites and cannot imagine driving BMWs. But most of them still enjoy substantially greater incomes and far greater access to the abundance offered by South Africa's 'first world' milieu than their poor brethren. Most have internalised many 'first world' habits of mind. All of this has usually, though not always, had a deracinating impact upon them and creates considerable psychological distance between them and even the urban and peri-urban poor within their segments. And since severe poverty is mainly found in rural areas, the distance between black elites and many or most of the poor within their segments is vast.

To make matters worse, a huge number of poor South Africans have also experienced deracination. In the apartheid era, many were uprooted as a consequence of state policy and the peculiar mixed economy which it helped to foster. They were deprived of pre-existing rights, not least to land, and families were broken apart by the need for breadwinners to migrate to urban settlements where anomie was rife, in search of work. The severe social dislocation experienced by deprived people wrought as much damage to the cohesion of social segments as did the process of elite formation within those segments. These trends have not been reversed since the collapse of apartheid. We have here a segmented society in which most of the segments are fractured beyond repair.

This is true even within the segment that was most cossetted by the apartheid regime: the Afrikaners. From the 1920s onward, the Afrikaner elite was famously concerned with the problems of the poor within their own segment. They had a well developed but perverse social consciousness towards the Afrikaner poor, and they sought to use state power to generate a 'sponsored bourgeoisie' that included as many Afrikaners as possible. ${ }^{6}$ However, as one telling analysis of recent history argues, by the early 1990 s - after many (but by no means all) Afrikaners had been enriched - F.W. de Klerk and the Afrikaner elite 'peacefully negotiated away their position of ethnic dominance' on the assumption that this would prevent the emergence of a radical new order. They reckoned (so far, correctly) that the 'rights culture of a liberal democracy' and 'the global predominance of a competitive market economy' would protect their material comforts. 'However, it meant that the poorer Afrikaners were left to fend for themselves in a vastly more hostile and competitive environment.' They sold out the poor Afrikaners (Adam et al., 1997: 58 and 61). Our interviews with members of Afrikaner elites revealed a suspicion among many that this was true.

(iv) Efforts to transcend segmentation Many of South Africa's political parties - especially, but not only the ANC - seek to develop broad-based social coalitions which cut across social segments. They do so because the imperatives of electoral politics demand it, and because it is in the interests of national integration and of the democratic process.

Many members of elites made it clear that they are also mightily preoccupied with the need to create a new, all-inclusive national identity which transcends segments. After apartheid, this is seen as a matter of urgency. But the progress that is occurring on this front undermines the already weak sense of obligation which elites feel towards poor people within their social segments. The building of broad coalitions tends to produce an important shift in elite perceptions. It encourages elites to become

\footnotetext{
' We are grateful to David Welsh for this point.
} 
preoccupied with the impersonal obligation of the government and the ruling party to tackle poverty and to de-emphasise their more personalised, philanthropic obligations within their social segments.

The four points discussed above are potent enough to undermine elite efforts to address the needs of the poor within their social segments. So we should not expect anti-poverty efforts within segments to achieve much. But at the same time, these four things do not erase social segmentation. It retains enough importance to impede the development both of a full social consciousness among most elites, and of a commitment among those elites to initiatives that address the needs of all the poor. This and the less-than-complete social consciousness among most elites creates serious problems for the ruling ANC elite, which is left with the task of addressing poverty. But they also face other difficulties in this matter. Let us now consider these.

\section{The Dilemmas of the ANC Elite}

A cruel, monumental irony confronts the ANC and South Africa's new government. They have attained power in the wake of an historic, global loss of confidence in centralised governance, and a major increase in the power of international market forces which demand fiscal discipline. The ANC faces popular pressure - which its inspirational rhetoric has partly fostered - to introduce massive change. Its remarkable success at gaining power, swiftly and peacefully, inspires a popular belief that further astonishing achievements are possible. So does the heroic quality of its leader, Nelson Mandela. And yet it operates in an era when even leftish governments are forced to engage in the less-than-heroic politics of modest adjustments.

Some of those governments present their programmes as 'radical' experiments, but they tend to be exercises in incrementalism on the cheap. Even moderately generous public spending, never mind expensive efforts at national reconstruction or social transformation, runs great risks. The liberationist agenda, on which the ANC fought the struggle against apartheid and the 1994 election, is akin those agendas which newly independent nations developed across Africa and Asia a generation or two ago. But times have changed, and this presents the ANC with agonising choices.

None is more painful than the decision on how to address mass poverty. When people in Europe and North America abandon elements of the 'social consciousness' which helped to drive redistribution and the creation of welfare states, and when governments retreat from their commitments to these goals, the consequences for the poor can be serious. But they are as nothing compared to the consequences in a country with South Africa's extreme inequalities and the crushing poverty that afflicts so many. ${ }^{7}$

Our interviews with members of the ANC elite indicate that they are torn between a persisting, exhilarating belief that all things are possible and a growing, dreary suspicion that in current conditions, only modest adjustments are feasible. The apartheid regime practiced racial discrimination on so many fronts that, at first, the new government could make numerous dramatic changes without spending much money. But most of those have now occurred. Those that remain, which include crucial, fundamental changes in structural conditions, require substantial funds. This leaves the ANC elite facing a choice between the goals of redistribution and growth.

Some critics - for example, John Pilger in a British television documentary - have accused the ANC elite of betraying the South African poor by yielding to pressure from the international arena and to the temptations of self-enrichment. These arguments are not wholly false. The need to court overseas investors clearly limits the government's capacity to pursue some redistributive programmes (although some international development agencies also encourage certain types of redistribution). And one ANC leader who famously spoke of the attractions of getting 'filthy rich' is not an isolated case. But the reality is far more complicated and ambiguous than the critics claim.

Many members of the ANC elite made it clear to us that they are acutely aware of the need to redistribute wealth in a society which is marked by extraordinary inequality. They want to do this, both

\footnotetext{
${ }^{7}$ We are grateful to Tony Leiman for this point.
} 
because it will promote social justice, and because it is politically necessary (or will eventually become necessary - an important distinction, as we shall see) if the ANC is to retain mass support. Evidence for their concern with redistribution emerges not just from interviews, but from the provisions for social and economic rights in the new Constitution, ${ }^{8}$ and from the ANC government's initial development strategy.

ANC policies on poverty have evolved over recent years. During the anti-apartheid struggle, it had proposed an assertively leftish approach. But by the time that the ANC assumed power, the Soviet bloc had disintegrated and most parties of the left in the OECD nations had adopted centrist or even centreright economic policies. This and the harsh economic conditions which South Africa faced ${ }^{9}$ persuaded the ANC to abandon ambitions to seize the commanding heights, but its continuing redistributionist inclinations (which still survive in many quarters) were evident in its first important initiative to tackle poverty - the Reconstruction and Development Programme (RDP).

The programme consists of four components, aimed at: (i) meeting basic needs (through job creation, land reform, programmes for housing, sanitation, water, electification, nutrition, health care, etc.); (ii) developing human resources (through education and training, literacy programmes, further education, the arts, sport, youth development, etc.); (iii) democratising state and society (in industry, agriculture, infrastructure efforts, reform of workers' rights and the financial sector, etc.); and (iv) building the economy (by addressing structural problems, creating jobs, tackling poverty, promoting workers' rights and skills, encouraging the improved use of technology, upgrading infrastructure, ending discrimination, encouraging stakeholding, etc.). ${ }^{10}$

Many members of the ANC elite and of South Africa's other elites see the RDP as a 'brilliant' plan. Some elements of it (in housing and the supply of

${ }^{8}$ This complex subject cannot be adequately treated in an article of this length. But see sections 7, 9, 26-29, 39 and $184(3)$ of the Constitution.

- See J. Matisonn in the Weekly Mail and Guardian, 6 and 13 November 1998; and Waldmeir, 1997, pp. $132-34$ and $252-58$. water, for example) are having a visible effect, and others (such as the new system of child support) will make a difference before long. But its impact has been seriously undermined by several things:

(i) a shortage of financial resources

(ii) a reluctance to impose new taxes

(iii) administrative incapacity

(iv) corruption

(v) limits on the government's power

(vi) the recent adoption of a more growth-oriented strategy which requires tight limits on public spending.

Even if ANC leaders had not subsequently imposed tight constraints on public spending, resources would have fallen well short of what is needed to make significant inroads into South Africa's vast 'social deficit'. It is theoretically possible to generate more resources by raising new taxes. But efforts to do so collide with two major impediments. First, substantial increases might alienate certain international agencies and cost the country vital assistance. Second and more crucially (as nearly all of our interviews showed), middle class South Africans from whom most resources might be raised see themselves as heavily over-taxed already. Successive budgets have avoided raising the income level at which higher income tax rates kick in, so now even the lower middle classes (including nearly all of the African members of elites that we interviewed) feel mightily burdened. They face an income tax bite of around $43 \%$, and pay substantial further taxes on consumer goods.

Administrative incapacity compounds the problem. Much of the bureaucracy is populated by those who served under the apartheid regime. The main problem is not that they act as saboteurs, but that they find it very difficult to adopt more responsive postures than in the old days - when they bestowed resources with considerable hauteur even to Afrikaners - to meet newly recognised needs in what is, for the first time, a demand-driven polity. ${ }^{11}$
10 'A Basic Guide to the Reconstruction and Development Programme' and 'The Reconstruction and Development Programmes: A Policy Framework', available at the South African Government web site www.polity.org.za/gnuindex.html.

"We are grateful to Johan van Zyl for stressing this. 
New people inserted by the ANC at the apex of the bureaucracy have begun to address this problem. But the size and diversity of the country has forced the central government to devolve many redistributive tasks onto provincial governments, some of which are of poor quality and prone to malfeasance.

The ANC elite has thus far restrained itself from the aggressive use of state power to pursue redistribution (despite a desire to do so, revealed in our interviews, among many in their ranks and among African elites more generally and even among some white elites). For example, it has not yet moved to compel private banks to make loans in support of low-income housing. It has also held back from assertive action on land redistribution.

Finally and crucially, the government has in recent times given pre-eminence to a second strand in its anti-poverty strategy. This is the 'Growth Employment and Restructuring' (GEAR) programme which entails stringent measures to maintain fiscal discipline in order to spur growth. It sits somewhat incongruously alongside the earlier RDP programme. For a while, ANC ministers were able to argue that GEAR had not resulted in a reduction in social spending. But even at that early stage, GEAR placed severe limits on any enhancement in existing redistributive programmes - which the minister of welfare frankly conceded were insufficient when the inherited social deficit was taken into account'. ${ }^{12}$ And by late 1998 , cuts in core areas of social spending had been announced. ${ }^{13}$

As a result of all this, the ANC will get nowhere near the fulfilment of the inflated promises of redistribution which it made at South Africa's first all-inclusive election in 1994. It is now clear that those promises were both unwise and unnecessary, since the party would have won a major victory without making them. But they are a reality with which ANC leaders must live. They face constant pressure from within their own ranks for more emphasis on redistribution and less on growth. ${ }^{14}$ Similar arguments often emerge from major think-tanks and even from the government's own studies. ${ }^{15}$ But the 1998 budget, while nodding in the direction of redistribution, stuck firmly to tight fiscal discipline, with growth as the overriding goal.

ANC elites justified this tough stance to us partly because they reckon that despite the shortfall in redistribution, enough will have been achieved in reversing the racist practices of the old regime and in addressing some basic needs of poor people to persuade them to back the ANC again at the next election in 1999. They may be right. As long as the apartheid regime remains the main point of comparison in the popular mind, even minimal achievements offer a glittering contrast. The opposition to the ANC remains badly fragmented, and opinion polls show no single opposition party gaining substantial support. All of this appears to give the ANC the luxury - which is unavailable to ruling parties in many other countries - of another five years or so to ensure that their strategies of redistribution and growth have a mass impact.

The ANC elite has one other, potent reason for pursuing growth as well as (and for the present, more assiduously than) redistribution. In interviews, they stressed that without growth, efforts at redistribution and affirmative action will be zero-sum games. They may be right, but a great deal hinges on whether their growth strategy will work. It has plainly not worked yet. GDP growth in 1997 was $1.9 \%$ at best, and expectations for 1998 have been scaled down from $3 \%$ to $0.2 \%$. These are alarmingly low figures, and even the finance minister's best hope for 1999 and 2000 are $2 \%$ and $3 \%$ respectively. ${ }^{16}$

subsequent years. The welfare budget loses R. 100 million in 1998-99, and will lose R. 100 million in 1999-2000 and another R. 200 million in the following year. (Financial Mail, 6 November 1998.)

${ }^{14}$ For example, union leaders appealled on the eve of the 1998 budget for a more aggressive effort at redistribution and poverty alleviation.

\footnotetext{
${ }^{15}$ See for example, Business Day, 8 and 14 May 1998.

${ }^{16}$ Financial Mail, 6 November 1998, and Weekly Mail and Guardian, 6 November 1998
} 
It seems inevitable to us that unless growth takes off unexpectedly and soon, ANC leaders will be forced by the expectations of their mainly poor supporters to shift their emphasis to redistribution. Some of them acknowledged this to us. That may be necessary even if growth picks up - if it is jobless growth that does little to help the poor. A change of emphasis will probably not occur to any great extent until after the election of mid-1999 which the ANC will surely win. But if the government persists with the present approach for more than a year or two thereafter, they risk the emergence of populist opposition parties that propose to soak the rich.

ANC leaders are acutely aware of this. A clear sign was provided in early November 1998 by no less than Thabo Mbeki, the president-in-waiting. In a speech to the upper house of parliament, he cited worrying statistics on inequality in South Africa:

The poorest $10 \%$ of households in the country received as little as $1 \%$ of all household income in 1995 , while the poorest $20 \%$ received only $3 \%$. The poorest $30 \%$ of households received only $5 \%$... while the poorest $50 \%$ received only $11 \%$...

The richest $20 \%$ of households had $65 \%$ of household income...

He then stressed the close link between race and the position of households in this hierarchy. He said that South Africa is in reality, made up of two nations, one black and poor and the other white and well off'. And he described this as 'an explosive mixture which has to be addressed if we are to guarantee stability for our country'. ${ }^{17}$

Mbeki may only have been seeking to protect the ANC from the (as yet) modest populist challenges which may arise in the 1999 election campaign. It is scarcely imaginable that his speech signals an effort to roll back the planned cuts in social spending which were announced in the same week. But if growth remains unimpressive in another two years, the pressure to move forcefully towards redistribution will become ferocious. In those circumstances,

\footnotetext{
${ }^{17}$ Cape Times, 11 November 1998.

${ }^{18}$ See for example, Wilson and Ramphele, 1989; and

Poverty and inequality in South Africa - summary
}

it would be astonishing if this highly astute and pragmatic leader failed to respond - indeed, in that speech he was positioning himself for just such a change in policy.

If (when) that happens, several of the things that we have learned about elite perceptions of poverty and poor people might be useful in crafting a strategy to 'sell' redistribution to elites, especially whites.

Certain elite misperceptions need to be addressed. Elites tend to the view that poverty is mainly an urban problem, and that it is less serious in rural areas where poor people have somehow always 'got by'. There is plenty of evidence available from good recent studies ${ }^{18}$ to disprove this, and efforts by Mbeki and company to do so might bear some fruit. Those same studies might be exploited to persuade elites that they are mistaken in their belief that South Africa's poor are better off in absolute terms than their counterparts in other African countries. An attempt also needs to be made to explain that inequality in South Africa is far more severe than in nearly all other countries. At present, elites tend to the view that places like Brazil and India are much more inequitable than South Africa.

Something also needs to be done to counter the elite tendency to exonerate themselves from any responsibility for poverty by projecting blame onto other groups and processes. They tend to blame apartheid, which most of them see as 'nothing to do with me' - and now that apartheid has been swept away, poverty is expected to decline in the normal course of events. The widespread elite view that the battle against poverty is the responsibility of government (which again is usually 'nothing to do with me') leads many to blame politicians and bureaucrats. Elites often see trade unions as important culprits, because they have forced wages in the organised sector to such heights that the poor suffer grievously. (There is some truth in this, but it is certainly not the central problem.) Many also blame the poor by arguing that they are lazy, unacquainted with the work ethic, and incapable of entrepreneurial effort. Elites tend believe that the 'first world' report', 13 May 1998, available at www.polity.org.za/govdocs/reports/presreview/index.html 
milieu which they inhabit offers the poor hope, when the reality is far more ambiguous than that.

If these notions can be dented, South Africa's elites may move closer to a belief in the interdependence of all groups in their society. If populist forces outside the ANC begin to gain ground, elites may be persuaded that the threat to their lifestyles and public order is sufficient to warrant serious efforts at redistribution. (Mbeki's recent reference to redistribution as a guarantee of stability was cleverly crafted to appeal to elite anxieties.) And if government can be shown to be growing in competence and effectiveness - as is likely in at least some spheres - elites may find it easier to believe that efficacious means (other than a surge in growth) exist or may be created to tackle poverty. None of these changes in view will occur in any complete sense, and they may not happen at all. But the perceptions of South African elites have moved far enough in recent years to suggest that the situation is far from hopeless.

\section{References}

Adam, H., F. Van Zyl Slabbert and K. Moodley, 1997, Comrades in Business: Post-Liberation Politics in South Africa, Cape Town: Tafelberg.

De Swaan, A., 1988, In Care of the State: Health Care, Education and Welfare in Europe and the USA in the Modern Era, Oxford: Polity Press.

Manor, J., 1996, "Ethnicity" and politics in India', International Affairs, July, pp. 459-76.

Waldmeir, P., 1997, Anatomy of a Miracle, Harmondsworth: Viking.

Wilson, F. and M. Ramphele, 1989, Uprooting Poverty: The South African Challenge, New York: WW. Norton. 